\title{
Achterstanden van niet-westerse immigranten op de arbeidsmarkt onder hoger opgeleide toetreders
}

Structurele, institutionele en sociaal-culturele factoren

Niels Raaijmakers, Lex Thijssen, Maurice Gesthuizen \& Maarten Wolbers

\author{
MEM 90 (1): 73-102
}

DOI: 10.1557/MEM2015.1.RAAI

\begin{abstract}
Summary
Labour market disadvantage amongst highly educated non-Western immigrants in the transition from school to work: The role of structural, institutional, and socio-cultural factors

This paper builds upon previous research on ethnic penalties in European labour markets by studying unemployment among higher educated nonwestern immigrant labour market entrants. By doing so, we attempt to get a better understanding of the extent to which one of the most advantaged immigrant groups still faces significant barriers in their search for work. We discuss to what extent structural-, institutional-, and socio-cultural characteristics of countries are able to explain cross-national variation in these inequalities between natives and non-western immigrants. Drawing upon pooled cross-section data from the European Labour Force Surveys (2005-2011), we test our hypotheses using a two-step multilevel method. Our analyses demonstrate that, first of all, higher educated non-western immigrant labour market entrants are more likely to be unemployed than their native counterparts. Second, we find that a higher percentage of foreigners in a country is positively associated with higher inequalities between immigrants and natives. However, in contrast to our expectation, governmental attempts to stimulate the integration of non-western immigrants are related to larger inequalities between non-western immigrants and natives among higher educated labour market entrants. Finally, we find inconclusive effects with regard to a country's immigration history.
\end{abstract}

Keywords: unemployment, higher educated immigrants, school-to-work transitions, two-step multilevel models, cross-national research 


\section{$1 \quad$ Inleiding}

Er bestaat veel onderzoek naar etnische ongelijkheden op de arbeidsmarkt (bijv. Altonji \& Blank, 1999; Heath, Rothon \& Kilpi, 2008). Diverse studies hebben reeds aangetoond dat niet-westerse immigranten substantiële achterstanden hebben in het onderwijs en in beroepsloopbanen (Heath, et al., 2008). Ook in recent onderzoek komt naar voren dat in vergelijking met autochtonen, niet-westerse immigranten een lager inkomen hebben, minder goede banen hebben en vaker werkloos zijn (Hermansen, 2013; Kogan, 2006; Luthra, 2013; Pichler, 2011; Reyneri \& Fullin, 2011).

Tot dusver bestaat er echter minder consensus over de vraag waarom immigranten deze achterstanden hebben op de arbeidsmarkt (Altonji \& Blank, 1999; Heath, et al., 2008). In lijn met de menselijk-kapitaaltheorie veronderstellen sommige onderzoekers dat deze ongelijkheden in grote mate kunnen worden toegeschreven aan groepsverschillen in werkgerelateerde vaardigheden. Anderen stellen echter dat factoren zoals discriminatie, de lagere sociale herkomst van immigranten, ineffectieve zoekmethoden om een baan te vinden, kleinere sociale netwerken en een gebrek aan landspecifiek kapitaal (bijv. Bertrand \& Mullainathan, 2004; Heath, et al. 2008; Kornrich, 2009; Livingstone, 2006; Maas \& Van Tubergen, 2006; Martinovic, Van Tubergen \& Maas, 2009; Van Tubergen, 2006; Van Tubergen, Maas \& Flap, 2004) van groter belang zijn om deze ongelijkheden te verklaren. In dit artikel proberen we een bijdrage aan dit debat te leveren door ons te richten op ongelijkheden tussen niet-westerse immigranten en autochtonen onder de hoger opgeleiden.

Eerder onderzoek heeft zich vooralsnog nauwelijks gericht op de kansen van hoger opgeleide immigranten, omdat in het algemeen verondersteld wordt dat de grootste achterstanden te vinden zijn in de lagere segmenten van de arbeidsmarkt, (Heath et. al, 2008, p. 216). Wij stellen echter dat onderzoek onder hoger opgeleide immigranten interessante inzichten kan opleveren over de invloed van menselijk kapitaal en discriminatie op de arbeidsmarkt. Met een focus op hoger opgeleide mensen met een nietwesterse nationaliteit, die bovendien hun opleiding hebben afgerond in het land van aankomst, kunnen we bepalen in hoeverre een groep die de beste vooruitzichten heeft op arbeidsmarktsucces (Drange, 2013; Urban, 2012) inderdaad hetzelfde bereikt als hun autochtone tegenhangers. Allereerst, doordat deze groep immigranten een hoog opleidingsniveau heeft behaald, is het aannemelijk dat zij over eenzelfde hoeveelheid menselijk kapitaal bezitten als autochtonen (Hall \& Farkas, 2012; Urban, 2012). Gezien het feit dat menselijk kapitaal een belangrijke voorspeller is van ar- 
beidsmarktsucces (Becker, 1993; Tomaskovic-Devey, Thomas \& Johnson, 2005), is te verwachten dat hoger opgeleide immigranten minder moeilijkheden ondervinden in het vinden van een baan. Daarnaast hebben studies aangetoond dat hoger opgeleiden tolerantere houdingen hebben ten aanzien van immigranten (Ceobanu \& Escandell, 2010). Ervan uitgaande dat werkgevers in de hogere segmenten van de arbeidsmarkt ook hoog opgeleid zijn, zou discriminatie nauwelijks een invloed moeten hebben op de carrières van hoger opgeleide immigranten. Kortom, op basis van deze argumenten zouden we verwachten dat we geen substantiële ongelijkheden zullen vinden in de hogere segmenten van de arbeidsmarkt. Echter, wat zegt ons het tot dusverre verzamelde empirisch bewijs?

In een aantal studies zijn etnische ongelijkheden onder hoogopgeleiden onderzocht. In Nederland, bijvoorbeeld, toonden veldexperimenten aan dat etnische minderheden minder vaak door werkgevers worden benaderd dan autochtonen ongeacht de status van de baan of het opleidingsniveau van de sollicitant (Andriessen, Nievers, Dagevos \& Faulk, 2012; Blommaert, Coenders \& Van Tubergen, 2014). Overeenkomstige resultaten kwamen naar voren in veldexperimenten onder hoger opgeleide sollicitanten in Duitsland en Zweden (Carlsson, 2010; Kaas \& Manger, 2012). In de Verenigde Staten observeerden Black, Haviland, Sanders \& Taylor (2006) en Pais (2011a) dat hoger opgeleide etnische minderheden en minderheden van hogere sociale herkomst nagenoeg evenveel verdienen als hun autochtone tegenpolen nadat was gecontroleerd voor verschillen in menselijk kapitaal. In Noors onderzoek vond men eveneens slechts geringe en niet significante inkomensverschillen in de carrières van allochtone en autochtone tandartsen en artsen, indien rekening gehouden werd met eerder opgedane werkervaring (Drange, 2013). Andere bevindingen in Noorwegen zijn evenwel niet in lijn met deze resultaten en laten duidelijke inkomensongelijkheden zien (Brekke, 2007; Brekke \& Mastekaasa, 2008). Ten slotte concludeert Rafferty (2012) op basis van zijn onderzoek in Engeland dat het opleidingsniveau geen nivellerend effect heeft op etnische ongelijkheden in beroepsstatus. Samenvattend kunnen we dus stellen dat eerder onderzoek wisselende resultaten laat zien en tevens inconsistente bevindingen tussen landen naar voren brengt.

In dit artikel bouwen we op twee manieren voort op bestaand onderzoek naar arbeidsmarktkansen van immigranten. In de eerste plaats doen we dit door verschillen in de werkloosheidskansen tussen hoger opgeleide autochtonen en immigranten met een niet-westerse nationaliteit te vergelijken tussen een groot aantal Europese landen. We veronderstellen dat hoogopgeleide niet-westerse immigranten, ondanks hun hoge opleiding, 
gemiddeld een groter risico lopen op werkloosheid in het begin van hun arbeidsmarktloopbaan dan hoogopgeleide autochtonen. We zullen dit in deze bijdrage 'de achterstand op de arbeidsmarkt van hoogopgeleide nietwesterse immigranten' noemen. Waar het merendeel van eerdergenoemde studies zich louter op één land richt, levert onze studie een bijdrage doordat we bestuderen in hoeverre landkarakteristieken crossnationale variatie in deze achterstand kunnen verklaren. Hierbij maken we gebruik van drie theoretische perspectieven, namelijk: een structureel-, een institutioneelen een sociaal-cultureel perspectief. Het structurele perspectief omvat factoren zoals de economische situatie en het percentage immigranten in een land. Het institutionele perspectief betreft voornamelijk factoren als de beroepsgerichtheid van het onderwijssysteem, arbeidsmarktregelingen en het overheidsbeleid om de integratie van immigranten te bevorderen. Het sociaal-culturele perspectief, ten slotte, gaat in op de vraag in hoeverre de sociaaldemocratische- en de immigratiegeschiedenis van een land crossnationale verschillen verklaren in de achterstand op de arbeidsmarkt van hoogopgeleide niet-westerse immigranten.

In de tweede plaats leveren we een bijdrage aan het onderzoek naar de overgang van school naar werk (zie bijv. Shavit \& Müller, 1998; Wolbers, 2007), omdat we ons richten op een tot op heden onderbelichte groep van arbeidsmarkttoetreders ${ }^{1}$, namelijk: hoger opgeleide niet-westerse immigranten. Gezien het feit dat achterstanden in het begin van arbeidsmarktloopbanen een belangrijke invloed hebben op iemands latere beroepspositie (DiPrete \& Eirich, 2006; Luijkx \& Wolbers, 2009), is het relevant om te zien in hoeverre hoger opgeleide niet-westerse immigranten meer moeilijkheden ondervinden in hun zoektocht naar een baan dan autochtonen. Aldus trachten we in dit onderzoek een antwoord te geven op de vraag:

In hoeverre kunnen we crossnationale variatie in de achterstand op de arbeidsmarkt van hoogopgeleide niet-westerse immigranten die de arbeidsmarkt betreden, verklaren vanuit een structureel,-, een institutioneel- en een sociaal-cultureel perspectief?

1 We beschouwen individuen als arbeidsmarkttoetreders als zij het dagonderwijs maximaal 10 jaar voor het moment van ondervraging hebben verlaten en zij tussen de 22 en 37 jaar oud zijn. 
Ter verklaring van crossnationale verschillen in de achterstand op de arbeidsmarkt van hoogopgeleide niet-westerse immigranten die de arbeidsmarkt betreden, bestuderen we zowel de vraag- als aanbodzijde van de arbeidsmarkt (Kornrich, 2009; Pais, 2011b). In het bijzonder stellen wij dat landkenmerken invloed uitoefenen op de preferenties van werkgevers, de capaciteiten en mogelijkheden van arbeidsmarkttoetreders met een nietwesterse nationaliteit, en de grootte van de groep immigranten op de arbeidsmarkt of in de samenleving. Achtereenvolgens bespreken we hier de effecten van structurele, institutionele en sociaal-culturele factoren.

\subsection{Structurele factoren}

Diverse structurele factoren kunnen wellicht de achterstand op de arbeidsmarkt van hoogopgeleide niet-westerse immigranten verklaren. Allereerst besteden we aandacht aan de economische situatie van een land. Diverse studies hebben uitgewezen dat in economisch ongunstige tijden met name arbeidsmarkttoetreders door hun gebrek aan werkervaring meer moeite hebben om een baan te vinden (De Lange, Gesthuizen \& Wolbers, 2014). Tevens is in onderzoek aangetoond dat etnische minderheden in een laagconjunctuur vaker werkloos zijn (Berthoud, 2000; Maas \& Van Tubergen, 2006). Deze bevindingen suggereren dat arbeidsmarkttoetreders met een niet-westerse nationaliteit mogelijkerwijs dubbel zo zwaar worden getroffen in een ongunstige economische situatie. Specifiek verwachten we dat deze ongunstige situatie zowel de bereidwilligheid als de mogelijkhedenstructuur voor discriminatie beïnvloedt.

Ten eerste vermoeden we op basis van de etnische-competitietheorie dat in een laagconjunctuur werkgevers sneller zullen discrimineren. Deze theorie stelt namelijk dat naarmate de competitie over schaarse goederen tussen verschillende etnische groepen intenser wordt (bijvoorbeeld over politieke invloed, culturele waarden of banen), of als intenser wordt gepercipieerd, gevoelens van etnische dreiging zullen toenemen (Scheepers, Gijsberts \& Coenders, 2002). Hierbij is het van belang om te benadrukken dat het niet om persoonlijk ervaren dreiging hoeft te gaan. Het feit dat de belangen van de eigen etnische groep worden getroffen kan ertoe leiden dat mensen meer etnische dreiging ervaren en daardoor meer geneigd zijn om leden van andere etnische groepen te discrimineren. Hieruit volgt dat ondanks het feit dat in een slechte economische situatie werkgevers niet direct worden getroffen door deze competitie om schaarse goederen, zij niettemin sneller geneigd zijn te discrimineren omdat zij de belangen van 
de eigen etnische groep trachten te beschermen. Naast de bereidheid tot discriminatie, verandert de economische situatie de mogelijkhedenstructuur voor discriminatie (Petersen \& Saporta, 2004). In economisch ongunstige tijden zullen werkgevers vaker discrimineren omdat ze de situatie kunnen gebruiken om selectiever te zijn in hun wervingsprocedures en ze het ontslag van immigranten beter kunnen rechtvaardigen. In deze situatie is het bovendien moeilijker om discriminatie vast te stellen of te bewijzen, waardoor werkgevers er vaker mee weg kunnen komen (Petersen \& Saporta, 2004). In economisch gunstige tijden is dit daarentegen juist makkelijker vast te stellen, omdat werkgevers een duidelijke afkeur van minderheden minder goed kunnen maskeren. Tevens zullen bedrijven om niet (verder) achterop te raken ten opzichte van directe concurrenten graag willen blijven uitbreiden en zullen zij zodoende minder selectief zijn in hun wervingsprocedures. We verwachten daarom:

H1: In landen met een ongunstige economische situatie zal de achterstand bij toetrede tot de arbeidsmarkt van hoogopgeleide niet-westerse immigranten groter zijn dan in landen met een gunstige economische situatie.

Afgezien van de economische situatie kan ook de grootte van de immigrantenpopulatie de relatieve positie van immigranten op de arbeidsmarkt bepalen, zij het op verschillende wijzen (Kornrich, 2009; Van Tubergen, et al., 2004). Enerzijds is het vanuit de etnische competitietheorie te veronderstellen dat de aanwezigheid van een grote immigrantenpopulatie in de samenleving gevoelens van etnische groepsdreiging doet toenemen, bijvoorbeeld doordat een grote populatie niet-westerse immigranten een bedreiging vormt voor de banen van autochtonen of omdat de culturele waardepatronen van de immigrantenpopulatie botsen met die van de autochtonen. Als gevolg hiervan zullen werkgevers vaker discrimineren om zo de belangen van de eigen etnische groep te beschermen (Ceobanu \& Escandell, 2010; Scheepers, et al., 2002). Anderzijds laat onderzoek zien dat een grotere immigrantengemeenschap een positief effect kan hebben op de arbeidsmarktkansen van immigranten (Van Tubergen, et al., 2004). In de eerste plaats zullen in landen met een procentueel groter aantal immigranten, immigranten een groter aandeel hebben in de compositie van de arbeidsmarkt. Doordat het aandeel immigranten in de arbeidsmarkt groter is, is hun relatieve positie ten opzichte die van autochtonen beter en is de kans daardoor groter dat zij een baan vinden (Kornrich, 2009; Reskin, 1991). In de tweede plaats heeft onderzoek uitgewezen dat immigranten in de 
grotere immigrantgemeenschappen werk kunnen vinden (Maas \& Van Tubergen, 2006; Van Tubergen, et al., 2004). In de literatuur staat dit ook wel bekend als 'etnisch kapitaal' (Van Tubergen, et al., 2004). De eigen gemeenschap dient dan als het ware als een sociaal vangnet voor leden die geen werk kunnen vinden buiten de gemeenschap. Op basis van deze inzichten stellen we de volgende tegengestelde hypothesen op:

H2: $\quad$ In landen met een grotere immigrantenpopulatie zal de achterstand bij toetrede tot de arbeidsmarkt van hoogopgeleide niet-westerse immigranten groter zijn dan in landen met een kleinere immigrantenpopulatie.

H3: In landen met een grotere immigrantenpopulatie zal de achterstand bij toetrede tot de arbeidsmarkt van hoogopgeleide niet-westerse immigranten kleiner zijn dan in landen met een kleinere immigrantenpopulatie.

\subsection{Institutionele factoren}

In crossnationaal onderzoek zijn de transities van het onderwijs naar de arbeidsmarkt uitgebreid bestudeerd (zie bijv. Breen, 2005; De Lange, et al., 2014; Noelke, Gebel \& Kogan, 2012; Shavit \& Müller, 1998; Wolbers, 2007). In dit onderzoek komt onder meer naar voren dat institutionele verschillen een grote rol spelen in de mate waarin deze overgangen voorspoedig verlopen. Het blijkt dat vooral in landen met een beroepsgericht onderwijssysteem arbeidsmarkttoetreders sneller een baan vinden dan in landen met een onderwijssysteem waarin studenten vooral algemene vaardigheden worden bijgebracht (Breen, 2005; De Lange, et al., 2014; Shavit \& Müller, 1998; Wolbers, 2007). De voornaamste reden hiervoor is dat in beroepsgerichte systemen de banden tussen het onderwijs en de arbeidsmarkt sterker zijn dan in academisch georiënteerde onderwijssystemen (Noelke, et al. 2012; Wolbers, 2007). Zo doen studenten, ten eerste, vaardigheden en kennis op die goed aansluiten op de behoeftes van werkgevers. Daarnaast leiden hechtere contacten tussen bedrijven en onderwijsaanbieders tot een sterkere beroepsoriëntatie in het studieprogramma, bijvoorbeeld doormiddel van stages en trainingen bij bedrijven. Ten slotte kunnen opleidingssystemen voornamelijk gevormd zijn rondom beroepsgerichte opleidingen zoals een opleiding tot docent of arts, of rondom sectoren waarin een grote vraag naar arbeid bestaat (bijv. de techniek). Deze sterkere verbondenheid met de arbeidsmarkt zorgt ervoor dat arbeidsmarkttoetreders erg aantrekkelijk zijn om aan te nemen. Dit is niet alleen het geval omdat werkgevers 
meer inzicht hebben in de capaciteiten van toetreders, maar ook omdat werkgevers de vaardigheden van studenten al in een vroegtijdig stadium hebben kunnen beoordelen en stimuleren.

In het algemeen zijn classificaties over de beroepsgerichtheid van het onderwijssysteem voornamelijk ontwikkeld voor het secundaire onderwijs. Echter, zoals Müller en Wolbers (2003) beargumenteren, is het niet mogelijk om deze classificaties één op één toe te passen op het tertiaire niveau. Daarom maken we gebruik van een typologie die speciaal is ontwikkeld voor onderwijssystemen op het tertiaire niveau. Deze typologie maakt onderscheid tussen uniforme, gediversifieerde en binaire systemen die variëren in de mate van beroepsgerichtheid (Shavit, Arum \& Gamoran, 2007; Willemse \& de Beer, 2012). In uniforme systemen wordt het tertiaire onderwijs aangeboden door één onderwijsinstelling. In gediversifieerde systemen is het onderwijs aangeboden door diverse instellingen die zowel beroepsgerichte- als academische cursussen aanbieden. Binaire systemen, ten slotte, bestaan uit twee afzonderlijke onderwijsrichtingen waarbij één richting academisch onderwijs aanbiedt en de andere voornamelijk het beroepsgeoriënteerde onderwijs verzorgt. In deze typologie wordt het binaire stelsel als het meest beroepsgerichte onderwijssysteem beschouwd, terwijl uniforme en gediversifieerde systemen minder beroepsgeoriënteerd zijn (Willemse \& de Beer, 2012).

De vraag is nu hoe deze verschillende onderwijssystemen de achterstand op de arbeidsmarkt van hoogopgeleide niet-westerse immigranten kunnen beïnvloeden. Om deze vraag te beantwoorden gaan we uit van statistische-discriminatietheorieën (Arrow, 1973; Phelps, 1972) en nemen we aan dat arbeidsmarktdiscriminatie het gevolg is van informatieonzekerheden over de werkcapaciteiten van met name geïmmigreerde niet-westerse sollicitanten. Deze theorieën veronderstellen dat, als gevolg van deze informatieonzekerheden, werkgevers stereotypen en groepsgemiddelden gebruiken om kandidaten te beoordelen (Bertrand \& Mullainathan, 2004; Pager \& Karafin, 2009). Omdat deze stereotypen en groepsgemiddelden vaak negatief zijn voor immigranten, wordt etniciteit als een negatieve proxy gezien voor iemands arbeidsproductiviteit en zullen immigranten daardoor minder vaak worden aangenomen. Echter, omdat beroepsgerichte onderwijssystemen werkgevers meer inzichten geven in de arbeidsmarktproductiviteit van individuen is het mogelijk dat werkgevers minder gebruik hoeven te maken van stereotyperingen om de arbeidsmarktproductiviteit van niet-westerse immigranten te beoordelen. Dit impliceert dat niet-westerse arbeidsmarkttoetreders minder vaak gediscrimineerd worden. Hypothese 4 luidt daarom: 
H4: In landen met meer beroepsgerichte onderwijssystemen zal de achterstand bij toetrede tot de arbeidsmarkt van hoogopgeleide niet-westerse immigranten kleiner zijn dan in landen met minder beroepsgerichte onderwijssystemen.

Ook de mate van arbeidsmarktbescherming kan de baanmogelijkheden beïnvloeden van niet-westerse arbeidsmarkttoetreders in vergelijking met die van autochtone toetreders. Studies tonen aan dat in landen met een strengere arbeidsmarktbescherming arbeidsmarkttoetreders meer moeite hebben om een baan te bemachtigen (zie o.a. Breen, 2005; De Lange, et al., 2014; Wolbers, 2007). De 'insider-outsider'-theorie levert hierbij relevante inzichten (Lindbeck \& Snower, 1988; 2002; De Lange, et al., 2014). In deze theorie staat centraal hoe 'insiders', de zittende werknemers, hun arbeidsposities beschermen ten koste van 'outsiders', oftewel personen die niet worden beschermd door arbeidsmarktwetgeving (zoals arbeidsmarkttoetreders en werklozen). De 'insider-outsider'-theorie stelt dat hogere ontslagkosten (bijv. afvloeiingsmaatregelen en senioriteitvoordelen) insiders macht geeft om hun posities te beschermen.

We voorspellen dat dit met name nadelig is voor arbeidsmarkttoetreders met een niet-westerse nationaliteit. Doordat niet-westerse immigranten in het algemeen nauwelijks zijn geïntegreerd in de hogere segmenten van de arbeidsmarkt (Heath, et al., 2008) bestaat er waarschijnlijk geen substantiële groep insiders die zich verantwoordelijk voelt voor de problemen van niet-westerse hoogopgeleide arbeidsmarkttoetreders. Tevens laat onderzoek zien dat zelfs als immigranten tot de insider-groep behoren, zij minder vaak (actief) lid zijn van vakbonden (Gorodzeisky \& Richards, 2013). Gezien de belangrijke rol die deze organisaties spelen in arbeidsmarktonderhandelingen, valt ook daarom te verwachten dat deze organisaties weinig oog hebben voor de problemen die niet-westerse immigranten ondervinden bij toetreding tot de arbeidsmarkt.

Een andere reden waarom een striktere arbeidsmarktbescherming kan leiden tot grotere achterstanden van mensen met een niet-westerse nationaliteit kan worden gezocht in statistische-discriminatietheorieën. Volgens deze theorieën worden (etnische) stereotypen gebruikt als een (negatieve) proxy voor onbekende arbeidsmarktcapaciteiten van sollicitanten met een niet-westerse nationaliteit. We verwachten dat dit effect sterker is indien wervingsbeslissingen minder omkeerbaar zijn, zoals het geval is indien landen strengere arbeidsbeschermingwetgeving hebben. Slecht presterende werknemers kunnen dan minder gemakkelijk ontslagen worden. Het gevolg is dat werkgevers vaker risicomijdende beslissingen maken en 
aldus minder vaak (niet-westerse) immigranten aannemen. Op basis van deze inzichten luidt hypothese 5 :

H5: In landen met strenge arbeidsmarktbescherming zal de achterstand bij toetrede tot de arbeidsmarkt van hoogopgeleide niet-westerse immigranten groter zijn dan in landen met minder strenge arbeidsmarktbescherming.

Ten slotte kunnen landen beleid implementeren om de integratie van (niet-westerse) immigranten te bevorderen. Onderzoekers hebben de effecten van verschillende vormen van overheidsbeleid en stimuleringsprogramma's onderzocht zoals taaltrainingen, grotere mogelijkheden om het staatsburgerschap te verkrijgen en antidiscriminatiewetwetgeving (Heath, et al., 2008; Koopmans, 2010; 2013; Pichler, 2011; Reitz, 2002). Ter illustratie, goede vooruitzichten om het staatsburgerschap te verkrijgen zouden ertoe leiden dat immigranten zich sneller verbonden voelen met het land van aankomst, waardoor zij meer moeite doen om zich in sociaaleconomisch opzicht te integreren. Specifiek voor de arbeidsmarkt kunnen regeringen beleid ontwikkelen dat de baankansen voor niet-westerse immigranten verbetert. Voorbeelden hiervan zijn strengere antidiscriminatiewetgeving en positieve-discriminatiemaatregelen die werkgevers moeten stimuleren vaker niet-westerse immigranten aan te nemen. Het effect van deze maatregelen is nog niet duidelijk empirisch bewezen (Koopmans, 2013; Pichler, 2011). Niettemin verwachten wij dat de positie van hoger opgeleide niet-westerse immigranten, in vergelijking met die van autochtonen, als gevolg van deze maatregelen beter zal zijn. Zodoende voorspellen wij:

H6: In landen die meer maatregelen treffen om de integratie van immigranten te bevorderen zal de achterstand bij toetrede tot de arbeidsmarkt van hoogopgeleide niet-westerse immigranten kleiner zijn dan in landen die minder maatregelen treffen om de integratie van immigranten te bevorderen.

\subsection{Sociaal-culturele factoren}

Tot slot bespreken we hoe de sociaaldemocratische geschiedenis en de immigratiegeschiedenis van een land crossnationale variatie kunnen verklaren in de achterstand op de arbeidsmarkt van hoogopgeleide niet-westerse immigranten. In landen met een lange sociaaldemocratische traditie hebben politici getracht om sociaaleconomische ongelijkheden aanzienlijk 
te verkleinen door de welvaartstaat steeds verder uit te breiden (Breen \& Jonsson, 2005). Op deze manier wilde men de invloed van iemands sociale achtergrond op zijn of haar toekomstige kansen op arbeidsmarktsucces verminderen. Naast instituties die de invloed van het sociale milieu zouden moeten inperken, zouden mensen in sociaal democratische staten in grotere mate gesocialiseerd zijn met normen en waarden van sociale gelijkheid (Parson, 1951). Met andere woorden, in sociaaldemocratische landen houden mensen zich wellicht meer aan de norm dat posities op de arbeidsmarkt dienen te worden verdeeld op basis van verworven eigenschappen van individuen (bijv. cognitieve vaardigheden en het opleidingsniveau) in plaats van toegeschreven eigenschappen (bijv. ouderlijke hulpbronnen of etniciteit). Aldus is te verwachten dat in landen met een langere sociaaldemocratische traditie er minder grote verschillen te zien zijn tussen autochtone en niet-westerse arbeidsmarkttoetreders omdat sociale achtergrond in mindere mate beslissend zou moeten zijn voor iemands latere baankansen.

In eerder onderzoek naar de baankansen van de totale populatie autochtonen en immigranten komen echter inconsistente bevindingen naar voren. Kogan (2006) vond bijvoorbeeld dat immigranten minder vaak werkloos waren in liberale welvaartsstaten dan in sociaaldemocratische welvaartstaten. Pichler (2011) vond daarentegen dat de kansen op arbeidsmarktsucces voor immigranten in sociaaldemocratische staten groter waren dan in andere welvaartsstaten. In hun onderzoek naar jeugdwerkloosheid in Europa vonden Maas en Van Tubergen (2006), ten slotte, geen significante effecten met betrekking tot de mate waarin sociaaldemocratische partijen vertegenwoordigd waren in de regering. In lijn met onze theoretische verwachtingen stellen wij nochtans:

H7: In landen met een langere historie van linkse partijen in het parlement zal de achterstand bij toetrede tot de arbeidsmarkt van hoogopgeleide niet-westerse immigranten kleiner zijn dan in landen met een kortere historie van linkse partijen in het parlement.

Niet alle landen hebben een zelfde geschiedenis met betrekking tot immigratiestromen. In Europa hebben voormalig koloniale grootheden als Frankrijk en Groot-Brittannië als samenleving meer ervaring met grote instromen van immigranten dan bijvoorbeeld Duitsland en de Scandinavische landen, die pas sinds de jaren ' 50 en '6o te maken hebben gekregen met een almaar groter wordende groep immigranten. Zuidelijk Europese landen zoals Spanje en Italië hebben pas sinds kort te maken met grote 
immigrantenstromingen. Volgens de assimilatietheorie (Alba \& Nee, 1997; Gordon, 1964; Van Tubergen, 2006) zullen immigratie- en integratieprocessen geleidelijk versoepelen naarmate, enerzijds, de autochtonen in deze samenlevingen meer gewend raken aan deze processen en, anderzijds, eerdere immigrantenpopulaties al beter geïntegreerd zijn in het land van aankomst. Onze laatste hypothese luidt dan ook:

H8: In landen met een langere immigratiehistorie zal de achterstand bij toetrede tot de arbeidsmarkt van hoogopgeleide niet-westerse immigranten kleiner zijn dan in landen met een kortere immigratiehistorie.

\section{Data en operationalisaties}

Om de geformuleerde hypothesen te toetsen hebben wij gebruik gemaakt van de European Union Labour Force Surveys (EULFS) afkomstig van Eurostat. Dit is een grootschalige representatieve dataset die 30 Europese landen bevat over een tijdsbestek van 20 jaar. De vragenlijst voorziet, vanuit verschillende perspectieven, informatie over werkgelegenheid en de arbeidsmarkt. In deze bijdrage hebben we gebruik gemaakt van vragenlijsten die zijn afgenomen in de periode tussen 2005 en 2011, omdat deze jaargangen genoeg hoger opgeleide niet-westerse immigranten bevatten.

In deze studie hebben we met een aantal selectiecriteria gewerkt. Ten eerste zijn 10 landen uit de data verwijderd als het gevolg van ontbrekende waarden op macro-level predictoren of de afwezigheid van hoger opgeleide immigranten in de dataset. ${ }^{2}$ Hierdoor bevat ons databestand 20 landen met gegevens over zeven jaar. Ten tweede zijn, gezien onze focus op hoger opgeleide arbeidsmarkttoetreders, louter respondenten met een tertiair opleidingsniveau (ISCED 5-6) in onze data opgenomen. Wanneer over de landen gekeken wordt, blijkt dat het percentage hoger opgeleide arbeidsmarkttoetreders met een niet-westerse nationaliteit (gepercenteerd over alle hoogopgeleide toetreders) over het algemeen laag ligt (0,9\% gemiddeld over alle landen). Ten derde nemen we, in navolging op eerder

2 In het databestand zijn de volgende landen opgenomen: Oostenrijk, België, Zwitserland, Tsjechië, Duitsland, Denemarken, Estland, Spanje, Finland, Frankrijk, Griekenland, Hongarije, Ierland, Italië, Luxemburg, Nederland, Portugal, Slowakije, Zweden en het Verenigd Koninkrijk. Cyprus, IJsland, Litouwen, Letland en Roemenië zijn verwijderd omdat deze ten minste één ontbrekende waarde hadden op een macro-level predictor. Bulgarije, Malta, Polen en Slovenië zijn niet in het databestand opgenomen, aangezien er met betrekking tot deze landen geen hoger opgeleide immigranten in de dataset zaten. 
onderzoek, enkel respondenten op die maximaal 10 jaar geleden hun opleiding hebben afgerond en tussen de 22 en 37 jaar oud zijn (zie bijv. De Lange, et al. 2014). Gezien wij ons richten op immigranten met een nietwesterse nationaliteit zijn immigranten met een westerse nationaliteit uit de data verwijderd. Daarnaast zijn immigranten met niet-westerse nationaliteit die hun opleiding in hun moederland hebben afgerond ook verwijderd uit de data, omdat deze diploma's niet altijd geheel equivalent zijn aan 'autochtone diploma's'. In totaal zijn verder 235.187 respondenten met een ontbrekende waarde op minimaal een gebruikte variabele door middel van listwise deletion verwijderd.

Tot slot hebben wij, gezien onze interesse naar macrovariabelen door de tijd heen, land-jaar combinaties geconstrueerd. Idealiter zou dit leiden tot $\left(20^{*} 7=\right) 140$ land-jaar combinaties. Echter, er zijn dertien land-jaar combinaties verwijderd omdat minimaal één macrovariabele bleek te onderbreken. Hierdoor werden 306.426 respondenten uit de data verwijderd. Uiteindelijk bevat onze dataset 829.518 respondenten verdeeld over 127 land-jaar combinaties.

\subsection{Microniveau variabelen}

Om werkloosheid (versus werkzaamheid) te meten hebben we gebruik gemaakt van de ILO werkstatus en deze vervolgens gecodeerd naar 'werkzame respondenten' (o) en 'werkloze respondenten' (1). Werkzamen zijn de respondenten met een betaalde baan. Werklozen hebben geen werk, maar zijn wel beschikbaar voor de arbeidsmarkt.

Immigrantenstatus is geoperationaliseerd aan de hand van de nationaliteit van de respondent. We hebben voor deze meting gekozen omdat deze meting beschikbaar is voor het grootste aantal land-jaar combinaties en we op basis hiervan het merendeel van de immigranten konden onderscheiden naar herkomstland. Een nadeel van deze meting is dat immigranten die genationaliseerd zijn hierdoor als autochtoon worden beschouwd. Overigens verwachten wij dat dit geen heel groot probleem zal zijn. Wanneer deze kleine groep van hoogopgeleide etnische minderheden samen wordt genomen in de referentiegroep met de grotere groep hoogopgeleide autochtonen, zal de invloed van eerstgenoemde groep op de effectschattingen (de verschillen in werkloosheidskansen tussen hoogopgeleide autochtonen en hoogopgeleide immigranten) naar onze verwachting minimaal zijn. We hebben uiteindelijk onderscheid gemaakt in vier categorieën, te weten 'autochtonen', 'niet-westerse immigranten', 'westerse immigranten' en 'overig'. In de analyse zijn de twee laatstgenoemde categorieën verwijderd. 
Daarnaast zijn zowel demografische (geslacht en burgerlijke staat) als opleidings- en arbeidsmarktkenmerken opgenomen als individuele kenmerken (opleidingsniveau, vakgebied en arbeidsmarktervaring). Vakgebied is als volgt gecategoriseerd 'Algemeen', 'Onderwijs', 'Letteren', 'Gamma', 'Bèta', 'Technisch', 'Agricultuur', 'Gezondheidszorg' en 'Openbare diensten' (Reimer, Noelke \& Kucel, 2008). Opleidingsniveau is gemeten door middel van de ISCED-schaal en bevat louter tertiair beroepsgericht en academisch onderwijs (ISCED 5 ) en postacademisch onderwijs (ISCED 6). Arbeidsmarktervaring, tot slot, is geoperationaliseerd door het verschil in tijd tussen het jaar van afstuderen en het enquêtejaar te nemen. De beschrijvende statistieken van deze individuele kenmerken zijn te zien in tabel 1.

\subsection{Macroniveau variabelen}

Dit artikel richt zich voornamelijk op de mate waarin macroniveau karakteristieken invloed hebben op de achterstand op de arbeidsmarkt van hoogopgeleide niet-westerse immigranten in Europese landen, in termen van hun relatieve werkloosheidskans ten opzichte van de autochtone bevolking. Om het structurele perspectief te operationaliseren maken we gebruik van de jaarlijkse statistieken van Eurostat. De economische situatie van een land is gemeten met het werkloosheidpercentage. Daarnaast is het aantal immigranten in een land (als percentage van de totale bevolking) gebruikt om de grootte van de totale groep immigranten aan te duiden. Bij deze meting is in drie gevallen lineair geïnterpoleerd om ontbrekende gegevens te kunnen schatten.

Drie institutionele kenmerken zijn gemeten. Ten eerste is de beroepsgerichtheid van het hogere opleidingssysteem gebaseerd op eerdere classificaties van Shavit et al. (2007) en Willemse \& De Beer (2012). We onderscheiden het binaire systeem, dat wordt gezien als het meest beroepsgeoriënteerd, van de overige opleidingssystemen. Arbeidsmarktbescherming is, ten tweede, geoperationaliseerd middels een index van de OECD. De OECD verzamelt jaarlijks data over de procedures en kosten voor bedrijven bij het ontslaan van hun werknemers (OECD, 2013). Deze gegevens zijn door de OECD samengevoegd in een index voor de striktheid van de arbeidsmarktbescherming die varieert tussen o (laagste niveau van arbeidsmarktbescherming) en 6 (hoogste niveau van arbeidsmarktbescherming). Onder minder striktere arbeidsmarktbescherming hebben werkgevers meer ruimte om werknemers te ontslaan. Om ontbrekende gegevens in te vullen zijn bij deze variabele zes cases lineair geïnterpoleerd. Ten derde zijn de maatregelen die een land treft ter stimulering van 
de integratie gemeten aan de hand van de MIPEX-index van 2007 en 2010. De Migrant Integration Policy Index is een evaluatie van integratiemaatregelen (zoals antidiscriminatie-wetgeving, arbeidsmarktprogramma's ontworpen voor immigranten, etc.) die in een land zijn geïmplementeerd. De index varieert tussen o en 100, waarbij een hogere score meer integratie stimulerende maatregelen indiceert. Ook bij deze meting ontbreken gegevens voor een aantal land-jaar combinaties. Deze gegevens hebben we als volgt aangevuld: aan de jaren voor 2007 is de score van de MIPEX van 2007 toebedeeld en de MIPEX-score van 2010 is aan dat betreffende jaar en de jaren daarna toegekend. De jaren tussen 2007 en 2010 zijn lineair geïnterpoleerd.

Tot slot zijn twee kenmerken van landen gemeten die van belang zijn volgens het sociaal-culturele perspectief. De historie van linkse partijen in de regering is gemeten middels data van de Database of Political Institutions (2012) afkomstig van The World Bank. Dit databestand bevat een grote hoeveelheid informatie (zoals de ideologische richting van het parlement) betreffende de partijcomposities van verscheidene regeringen tussen 1971 en 2011. In overeenstemming met Levels, Dronkers en Kraaykamp (2008) is voor elk land en jaar tussen 1971 en 2011 gecodeerd of er sprake was van een coalitie van voornamelijk linkse partijen (1), een combinatie van linkse en niet-linkse partijen (0.5) of zonder linkse politieke partijen (o). Deze scores zijn vervolgens bij elkaar opgeteld. Dit leidt tot een index waarvoor geldt dat een land een langere historie van linkse partijen heeft naarmate het hoger scoort. Betreffende de immigratiegeschiedenis van een land maken we onderscheid tussen drie categorieën: landen die al voor 1970; pas tussen 1970 en 1990; en pas na 1990 een grote toestroom van immigranten zagen (gebaseerd op Castles \& Miller, 2003; Heath, et al, 2008).

De beschrijvende statistieken voor de micro- en macro-level karakteristieken zijn te zien in tabel 1. 
Tabel 1 Beschrijvende statistieken van micro- en macrokarakteristieken

\begin{tabular}{|c|c|c|c|c|}
\hline & Minimum & Maximum & Gemiddelde & Std. deviatie \\
\hline \multicolumn{5}{|c|}{ Individuele karakteristieken ( $\mathrm{N}=826.815$ ) } \\
\hline Werkloosheid & 0,00 & 1,00 & 0,078 & \\
\hline Niet-westerse immigranten & 0,00 & 1,00 & 0,010 & \\
\hline ISCED 6 & 0,00 & 1,00 & 0,022 & \\
\hline Man & 0,00 & 1,00 & 0,444 & \\
\hline \multicolumn{5}{|l|}{ Burgerlijke staat } \\
\hline Getrouwd & 0,00 & 1,00 & 0,294 & \\
\hline Uit elkaar & 0,00 & 1,00 & 0,015 & \\
\hline Single & 0,00 & 1,00 & 0,691 & \\
\hline \multicolumn{5}{|l|}{ Vakgebied } \\
\hline Onderwijs & 0,00 & 1,00 & 0,099 & \\
\hline Kunsten & 0,00 & 1,00 & 0,101 & \\
\hline Gamma & 0,00 & 1,00 & 0,334 & \\
\hline Bèta & 0,00 & 1,00 & 0,097 & \\
\hline Technisch & 0,00 & 1,00 & 0,162 & \\
\hline Agricultuur & 0,00 & 1,00 & 0,021 & \\
\hline Gezondheidszorg & 0,00 & 1,00 & 0,138 & \\
\hline Diensten & 0,00 & 1,00 & 0,047 & \\
\hline Arbeidsmarktervaring & 0,00 & 10,00 & 4,777 & 2,984 \\
\hline Jaar afronding onderwijs & 1995,00 & 2011,00 & 2003,310 & 3,623 \\
\hline \multicolumn{5}{|l|}{ Macrokarakteristieken $(\mathrm{N}=127)$} \\
\hline Werkloosheidspercentage & 3,10 & 21,40 & 7,805 & 3,421 \\
\hline Percentage allochtonen & 0,00 & 0,44 & 0,094 & 0,093 \\
\hline Onderwijssysteem & & & & \\
\hline Gediversifieerd & 0,00 & 1,00 & 0,354 & \\
\hline Binair & 0,00 & 1,00 & 0,543 & \\
\hline Uniform & 0,00 & 1,00 & 0,102 & \\
\hline Arbeidsmarktbescherming & 1,20 & 4,42 & 2,406 & 0,718 \\
\hline MIPEX-index & 36,27 & 84,70 & 56,794 & 12,713 \\
\hline Historie linkse partijen & 5,00 & 26,00 & 14,768 & 5,417 \\
\hline \multicolumn{5}{|l|}{ Immigratiehistorie } \\
\hline Instroom immigratie voor 1970 & 0,00 & 1,00 & 0,535 & \\
\hline Instroom immigratie voor 1990 & 0,00 & 1,00 & 0,299 & \\
\hline Instroom immigratie na 1990 & 0,00 & 1,00 & 0,165 & \\
\hline \multicolumn{5}{|l|}{ Jaar van de enquête } \\
\hline 2005 & 0,00 & 1,00 & 0,142 & \\
\hline 2006 & 0,00 & 1,00 & 0,158 & \\
\hline 2007 & 0,00 & 1,00 & 0,134 & \\
\hline 2008 & 0,00 & 1,00 & 0,134 & \\
\hline 2009 & 0,00 & 1,00 & 0,134 & \\
\hline 2010 & 0,00 & 1,00 & 0,142 & \\
\hline 2011 & 0,00 & 1,00 & 0,158 & \\
\hline
\end{tabular}

Bron: European Labour Force Survey, 2005-2011 


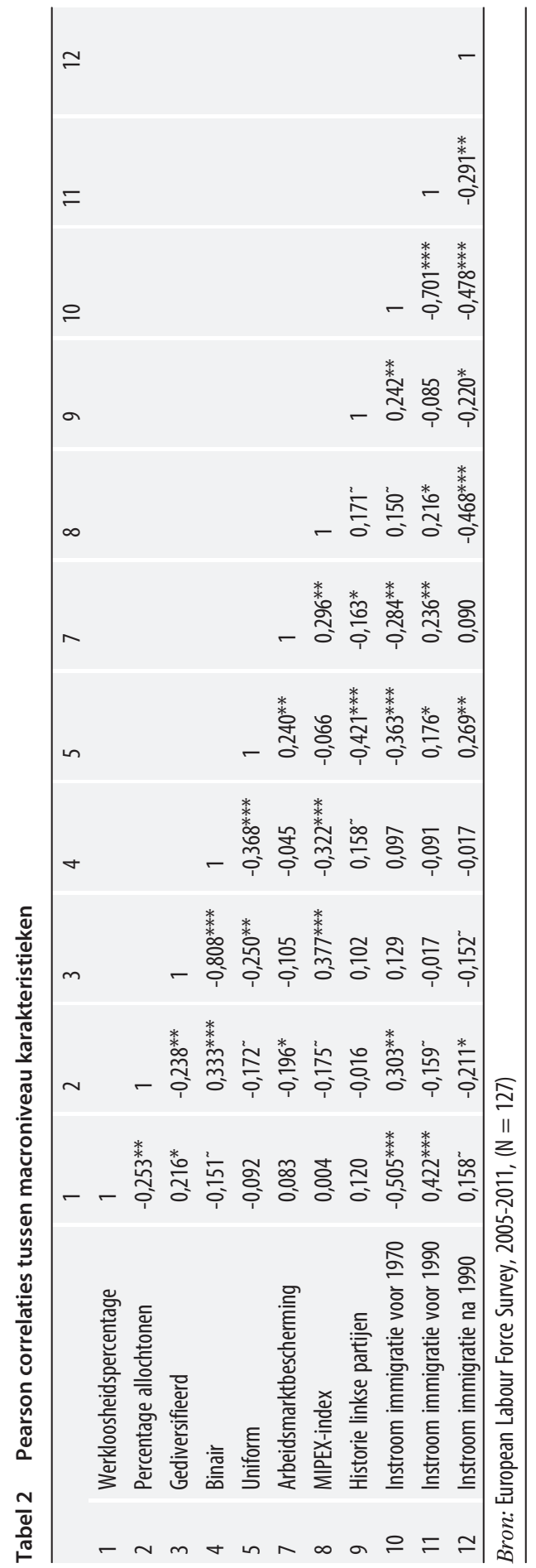




\section{Analyses}

\subsection{Methoden}

Gewoonlijk zouden de in deze studie geformuleerde hypothesen getoetst kunnen worden met behulp van multiniveau-analyse. Echter, prefereren wij hier een tweestaps multiniveau aanpak (zie ook: Reimer et. Al, 2008; Gebel \& Giesecke, 2011; Abrassart, 2013). Tweestaps multiniveaumodellen krijgen hier om meerdere redenen de voorkeur. Ten eerste staan tweestapsmodellen een flexibelere specificatie van individuele modellen toe, waardoor deze mogen variëren en niet gelijk hoeven te zijn tussen landjaar combinaties (Gebel \& Giesecke, 2011; Abrassart, 2013). Een tweede reden voor onze voorkeur ligt in het aantal observaties dat nodig is voor robuuste resultaten in een model met een grote selectie macrokarakteristieken (Rijken, 1999, p. 17; Abrassart, 2013). In gewone multiniveau modellen, is het schatten van robuuste parameters in een model met een grote selectie macrovariabelen lastig. Gezien dit bij tweestapsmodellen minder grote problemen oplevert, prefereren wij deze analysemethode.

In de eerste stap wordt per land-jaar combinatie een logistisch model met werkzaamheid/werkloosheid als afhankelijke variabele geschat. Dit model bevat naast immigrantstatus de variabelen geslacht, opleidingsniveau, burgerlijke staat, vakgebied, arbeidsmarktervaring en het jaar waarin de opleiding afgerond is.

In de tweede stap worden OLS-regressiemodellen met macrokenmerken geschat. In deze stap functioneren de (gecontroleerde) coëfficiënten van immigrantenstatus (versus autochtonen) op de werkloosheidskans (versus werkzaamheid) van de eerste stap als afhankelijke variabele voor iedere land-jaar combinatie die is opgenomen in dit macromodel. Dit impliceert dat een effect van een macrokarakteristiek geïnterpreteerd dient te worden als een effect op de logit van immigrantstatus op werkloosheid. Hierdoor kunnen de geschatte coëfficiënten behandeld worden als het equivalent van 'cross-level' interactietermen, zoals deze in multiniveau modellen gebruikt worden. Neemt de score op een macrokenmerk toe (is het werkloosheidspercentage in een land-jaar combinatie bijvoorbeeld hoger) en is er sprake van een positieve regressiecoëfficiënt, dan betekent dit dat onder deze omstandigheden de relatieve werkloosheidskans onder niet-westerse hoogopgeleide immigranten die toetreden tot de arbeidsmarkt, en daarmee hun achterstand op de arbeidsmarkt, groter is. Een negatieve regressiecoëfficiënt impliceert een kleinere achterstand (gegeven dat gemiddeld over alle land-jaar combinaties hoogopgeleide niet-westerse 
immigranten die de arbeidsmarkt betreden een grotere werkloosheidskans hebben dan hun autochtone tegenpolen).

De toepassing van deze tweede stap kent echter enkele haken en ogen. In de eerste plaats kunnen de in de eerste stap geschatte coëfficiënten over- of onderschat worden als gevolg van variatie in de standaardfout van de coëfficiënten. Dit beïnvloedt de betrouwbaarheid van de immigrantcoëfficiënten en, in het verlengde hiervan, de macrocoëfficiënten. Om hiervoor te corrigeren hebben we elke land-jaar combinatie gewogen in overeenstemming met de inverse van de standaardfout van de immigrantcoëfficiënt. In de tweede plaats kunnen door het gebruik van landjaar combinaties meetfouten ontstaan als gevolg van statistische afhankelijkheid. Het is namelijk plausibel dat een land in 2011 sterk correleert met hetzelfde land in een ander jaar. Gezien wij voornamelijk geïnteresseerd zijn in crossnationale verschillen, en in minder mate geïnteresseerd zijn in verschillen tussen jaren, is er besloten om in de analyse te controleren voor het jaar waarin de enquête is afgenomen. Zodoende pogen wij de crossnationale verschillen in werkeloosheidskansen, tussen hoger opgeleide arbeidsmarkttoetreders met een niet-westerse nationaliteit en hun autochtonen tegenhangers, zo zuiver mogelijk te schatten.

\subsection{Resultaten}

In de eerste stap schatten we de logit voor hoogopgeleide arbeidsmarkttoetreders met een niet-westerse nationaliteit per land-jaar combinatie. Figuur 1 presenteert de significante resultaten uit de eerste stap. De logits variëren aanzienlijk over land-jaar combinaties. De verschillen in de grootte van de werkloosheidskans tussen hoogopgeleide autochtone en niet-westerse arbeidsmarkttoetreders zijn het meest in het nadeel van niet-westerse immigranten in Hongarije 2008 (3,22), terwijl we in Frankrijk 2008 de kleinste verschillen observeren (0,56). In Griekenland 2011 zien we juist een significant negatieve coëfficiënt $(-0,94)$ wat erop duidt dat niet-westerse immigranten een kleinere kans hebben op werkloosheid. 

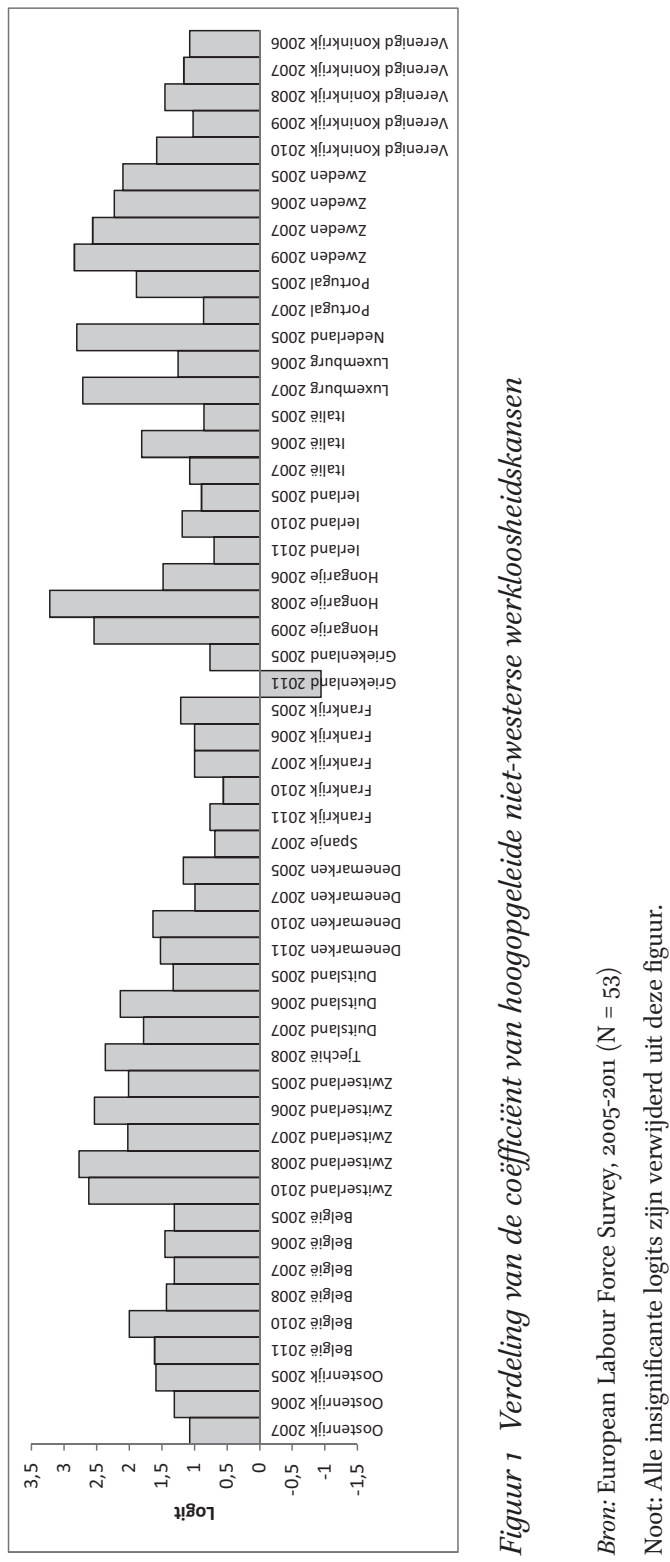

De resultaten van de tweede stap staan gepresenteerd in model o tot en met 4 van tabel 3. Het nulmodel illustreert de gemiddelde (gewogen) coëfficiënt van de logit. Het intercept in dit model is positief en significant (B $=1,096$; standaardfout $=0,070$ ), wat aangeeft dat gemiddeld over de landen en jaren hoger opgeleide arbeidsmarkttoetreders met een niet-westerse 
nationaliteit inderdaad een grotere kans hebben om werkloos te zijn dan hun autochtone tegenpolen.

Model 1 schat de effecten afgeleid uit de drie theoretische perspectieven gezamenlijk. Hypothese 1 stelde dat in landen met een ongunstige economische situatie de achterstand bij toetrede tot de arbeidsmarkt van hoogopgeleide niet-westerse immigranten groter is dan in landen met een gunstige economische situatie. Het effect van de werkloosheidcijfers is niet significant en bovendien in de verkeerde richting. We vinden daarom geen ondersteuning voor hypothese 1 . We vinden een positief significant effect van het percentage immigranten in een land. Deze bevinding is in lijn met hypothese 2 waarin werd verwacht dat in landen met een grotere immigrantenpopulatie de achterstand bij toetrede tot de arbeidsmarkt van hoogopgeleide niet-westerse immigranten groter zou zijn dan in landen met een kleinere immigrantenpopulatie. De tegengestelde hypothese 3 vindt zodoende geen ondersteuning.

Met betrekking tot het institutionele perspectief zien we, allereerst, een (licht) significant positief effect van binaire onderwijssystemen, ten opzichte van gediversifieerde onderwijssystemen. Dit houdt in dat de achterstand bij toetrede tot de arbeidsmarkt van hoogopgeleide niet-westerse immigranten groter is in landen met een meer beroepsgericht onderwijssysteem. Dit is een bevinding die niet in overeenstemming is met hypothese 4 . We vinden verder geen effect voor uniforme onderwijssystemen. Hypothese 5 hield in dat in landen met een strenge arbeidsmarktbescherming de achterstand bij toetrede tot de arbeidsmarkt van hoogopgeleide niet-westerse immigranten groter zal zijn dan in landen met minder strenge arbeidsmarktbescherming. We vinden in model 1 een negatief en niet-significant effect van arbeidsmarktbescherming en, zodoende, geen ondersteuning voor deze verwachting. Het effect van de MIPEX-index is significant en positief ( $0.031, \mathrm{p}<0.001)$. Met andere woorden, in landen die meer maatregelen treffen om de integratie van immigranten te bevorderen is de achterstand bij toetrede tot de arbeidsmarkt van hoogopgeleide nietwesterse immigranten groter dan in landen die minder maatregelen treffen om de integratie van immigranten te bevorderen. Hypothese 6 wordt aldus niet ondersteund.

We stelden twee hypothesen op voor het sociaal-cultureel perspectief. Hypothese 7 stelde dat in landen met een langere historie van linkse partijen in het parlement de achterstand bij toetrede tot de arbeidsmarkt van hoogopgeleide niet-westerse immigranten kleiner is dan in landen met een kortere historie van linkse partijen in het parlement. Het effect van de historie van linkse partijen is niet significant waardoor we geen ondersteu- 
ning vinden voor hypothese 7 . Met betrekking tot hypothese 8 vinden we gemengde resultaten. In tegenstelling tot deze hypothese vinden we dat de achterstand bij toetrede tot de arbeidsmarkt van hoogopgeleide niet-westerse immigranten kleiner is in landen die vanaf de periode tussen 1970 en 1990 een grote toestroom van immigranten hebben gezien, in vergelijking met landen met een lange immigratiegeschiedenis (beginnend voor 1970). In landen met een korte immigratiegeschiedenis (vanaf 1990) is de achterstand bij toetrede tot de arbeidsmarkt van hoogopgeleide niet-westerse immigranten groter dan in landen met een lange immigratiegeschiedenis. Dit is wel in overeenstemming met hypothese 8 .

Model 2 laat alleen de resultaten voor het structurele perspectief zien, zonder dat deze zijn gecorrigeerd voor verschillen tussen landen in institutionele en sociaal-culturele factoren. Zonder deze controles op het macroniveau blijken werkloosheidcijfers een - onverwacht - negatief effect te hebben op de logit van niet-westerse immigranten. In landen met minder gunstige economische omstandigheden is de achterstand bij toetrede tot de arbeidsmarkt van hoogopgeleide niet-westerse immigranten kleiner is dan in landen met gunstigere economische omstandigheden. Daarnaast zien we, hoewel het effect marginaal significant is, wederom dat het percentage immigranten in een land de achterstand bij toetrede tot de arbeidsmarkt van hoogopgeleide niet-westerse immigranten vergroot. De MIPEX-index, de historie van linkse partijen en de immigratiegeschiedenis van landen zijn verantwoordelijk voor het onderdrukte effect in model 2 (want het effect is groter in model 1, waarin alle macrokenmerken zijn opgenomen).

In model 3 worden de effecten van het institutionele perspectief getoond. Ook hier komt naar voren dat de achterstand bij toetrede tot de arbeidsmarkt van hoogopgeleide niet-westerse immigranten groter is in landen met een meer beroepsgericht onderwijssysteem. Verder blijkt dat in dit model arbeidsmarktbescherming - tegen de verwachting - negatief samenhangt met de logit van niet-westerse immigranten. Net als in model 1 vinden we ook hier dat integratie bevorderende maatregelen in een land samen gaan met een grotere achterstand bij toetrede tot de arbeidsmarkt van hoogopgeleide niet-westerse immigranten.

Model 4, tot slot, toont de afzonderlijke resultaten voor het sociaalculturele perspectief. De historie van linkse partijen in een regering blijkt ook in dit model geen invloed te hebben op de relatieve werkloosheidskansen van hoger opgeleide immigrante arbeidsmarkttoetreders. We zien wederom wel dat in landen die tussen 1970 en 1990 een grote toestroom van immigranten hebben gezien de achterstand bij toetrede tot de arbeids- 
markt van hoogopgeleide niet-westerse immigranten kleiner is dan in landen die een dergelijke toestroom hebben gezien voor 1970. Het effect van landen die na 1990 een grote toestroom immigranten hebben gezien is evenwel niet significant.

Tabel 3 OLS-regressie van de relatieve werkloosheidskans van hoogopgeleide niet-westerse migranten versus autochtonen (geïndiceerd door land- en jaarspecifieke logit-coefficienten)

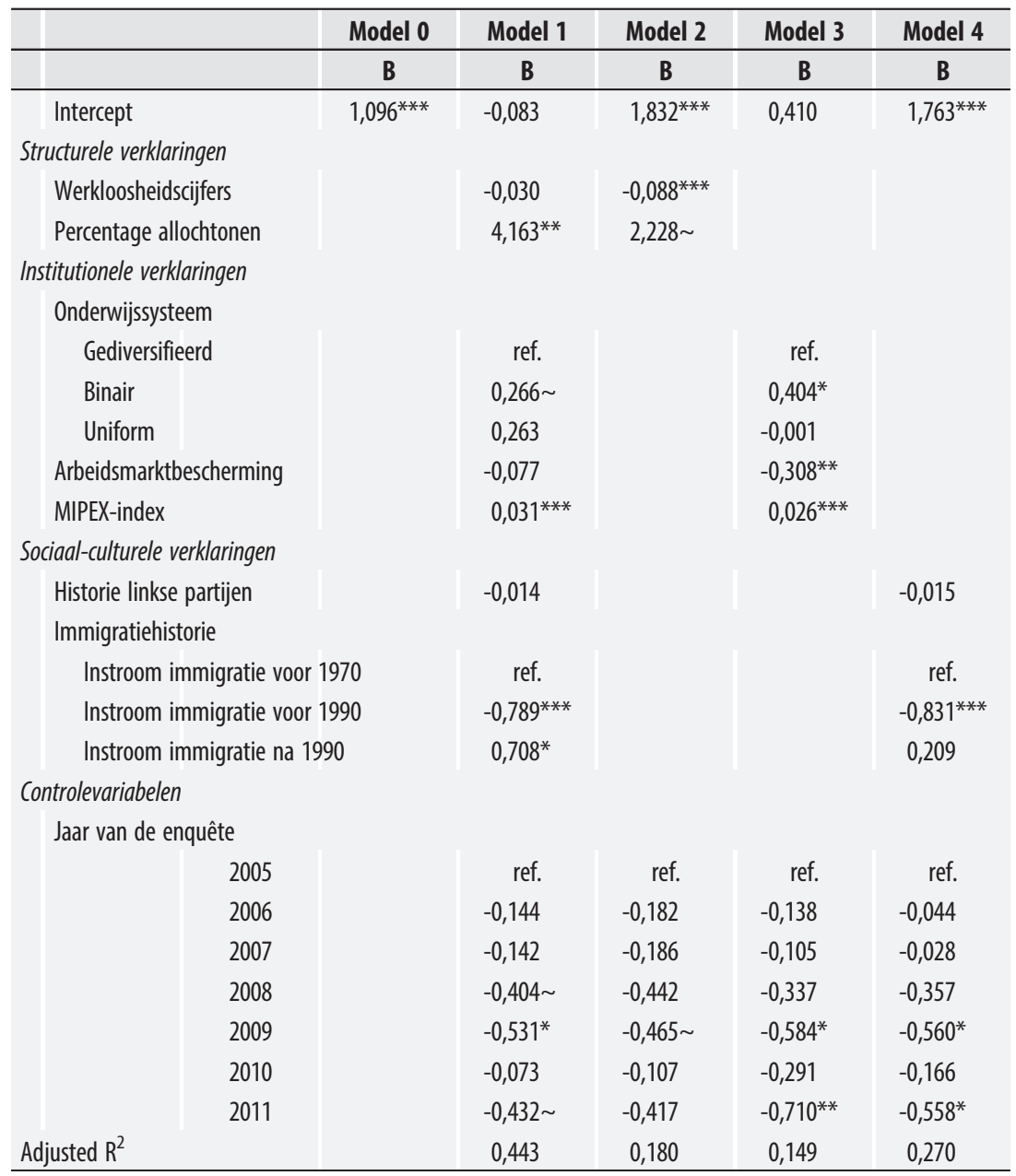

Noot: $\mathrm{N}=127,{ }^{* * * P}<0,001 ;{ }^{* * P}<0,01 ;{ }^{* P}<0,05 ;{ }^{\sim} \mathrm{P}<0,1$

Bron: European Labour Force Survey, 2005-2011 


\section{$5 \quad$ Conclusie en discussie}

In dit onderzoek hebben wij getracht eerder onderzoek naar etnische ongelijkheden op de Europese arbeidsmarkten uit te breiden. Door ons te richten op de hoger opgeleide niet-westerse immigrantengroep die tot de arbeidsmarkt toetrad, hoopten wij aan te kunnen duiden in hoeverre een niet-westerse immigrantengroep met de meest gunstige uitgangssituatie alsnog significante tegenslagen ondervindt in hun zoektocht naar een baan. Specifiek bestudeerden we in hoeverre structurele, institutionele en sociaal-culturele kenmerken van landen crossnationale variatie in de verschillen in de werkloosheidskans tussen hoogopgeleide autochtone en niet-westerse arbeidsmarkttoetreders konden verklaren. Onze hypothesen zijn getoetst met behulp van de European Labour Force Surveys (tussen 2005 en 2011).

De bevindingen van deze studie illustreren, ten eerste, dat gemiddeld over alle land-jaar combinaties hoger opgeleide niet-westerse arbeidsmarkttoetreders een grotere kans hebben om werkloos te zijn dan hun autochtone tegenpolen. In ongeveer de helft van alle land-jaar combinaties was dit verschil significant. In dit opzicht kwamen onze resultaten overeen met eerder onderzoek naar hoger opgeleide immigranten en andere crossnationale onderzoeken naar arbeidsmarktverschillen (zie o.a. Andriessen et al., 2012; Blommaert et al., 2014; Carlsson, 2010; Kaas \& Manger, 2012; Kogan, 2006; Maas \& Van Tubergen, 2006; Pichler, 2011).

Betreffende onze hypothesen bleken onze resultaten, ten tweede, ten dele het structurele perspectief te ondersteunen. In overeenstemming met de etnische-competitietheorie vinden we dat een hoger percentage allochtonen in een land samenhangt met een grotere achterstand bij toetrede tot de arbeidsmarkt van hoogopgeleide niet-westerse immigranten. Soortgelijke effecten voor de economische situatie van een land zijn echter niet gevonden (cf. Maas \& Van Tubergen, 2006).

Ten derde bieden onze resultaten geen ondersteuning voor de hypothesen geformuleerd onder het institutionele perspectief. Arbeidsmarktbescherming hangt niet samen met de achterstand bij toetrede tot de arbeidsmarkt van hoogopgeleide niet-westerse immigranten (cf. Maas \& Van Tubergen, 2006; Pichler, 2011). Met betrekking tot beroepsgerichtheid van het onderwijssysteem en het aantal integratie stimulerende maatregelen vinden wij voornamelijk resultaten tegenovergesteld aan onze hypothesen. Mogelijkerwijs kunnen eerdere achterstanden in de onderwijscarrière het onverwachte effect van binaire onderwijssystemen verklaren. Onderzoek naar het hogere secundaire niveau van het Noorse binaire onder- 
wijssysteem laat bijvoorbeeld zien dat studenten met een niet-westerse nationaliteit een kleinere kans hebben op een stageplaats dan autochtonen (Helland \& Støren, 2006). Daarom illustreren deze bevindingen dat meer beroepsgerichte onderwijssystemen niet per se informatieonzekerheden wegnemen omtrent de arbeidsmarktproductiviteit van deze groep arbeidsmarkttoetreders. Aanvullend kunnen twee alternatieve verklaringen worden geopperd voor het tegengestelde effect van integratiemaatregelen. Enerzijds zouden integratiemaatregelen averechts kunnen werken omdat ze, bijvoorbeeld, scepticisme ten opzichte van de daadwerkelijke arbeidsmarktproductiviteit van immigranten oproepen (zie ook Quillian. 20o6, p. 312). Anderzijds speelt een causaliteitsprobleem hier mogelijk een rol omdat een hoge mate van discriminatie zou kunnen leiden tot meer sociaaleconomische integratie bevorderende overheidsmaatregelen.

Ten vierde wordt het sociaal-culturele perspectief eveneens niet geheel ondersteund door onze analyses. De historie van linkse partijen in de regering hangt niet samen met de achterstand bij toetrede tot de arbeidsmarkt van hoogopgeleide niet-westerse immigranten (cf. Maas \& Van Tubergen, 2006, maar zie ook Kogan, 2006). Dit bleek wel het geval voor de immigratiehistorie van een land. In tegenstelling tot onze verwachtingen bleek, in vergelijking met landen met een lange immigratiehistorie, dat in landen met een gematigd lange geschiedenis de achterstand bij toetrede tot de arbeidsmarkt van hoogopgeleide niet-westerse immigranten kleiner is. Daarentegen vonden we in overeenstemming met onze hypothese wel dat in landen met een korte immigratiegeschiedenis er een grotere achterstand is bij toetrede tot de arbeidsmarkt van hoogopgeleide niet-westerse immigranten. Hier zou de betrekkelijk korte tijd om te assimileren een rol kunnen spelen.

Een algemene beschouwing van onze resultaten leert ons dat de immigrantengroep met de beste uitgangspositie nog steeds te maken heeft met substantiële achterstanden op de arbeidsmarkt. Hoewel wij plausibele verklaringen hebben aangedragen voor verschillen tussen landen in deze achterstand, gebaseerd op drie perspectieven, kwam geen enkel perspectief, en de daarbij behorende onderliggende theoretische verklaringen, echt overtuigend uit de verf en blijft toekomstig onderzoek noodzakelijk. Deze bevindingen tonen niettemin andermaal de hardnekkigheid aan van het integratieprobleem in Europese samenlevingen.

Ondanks dat deze studie enkele nieuwe inzichten heeft verschaft betreffende etnische ongelijkheden op de arbeidsmarkt, kent zij ook enkele beperkingen die de basis voor toekomstig onderzoek kunnen vormen. Allereerst is het mogelijk dat dit onderzoek te maken heeft met niet waar- 
genomen heterogeniteit die, ondanks een uitgebreide set van controlevariabelen, de achterstand van migranten mogelijk onder- of overschatten. Zo zouden selectieve migratiestromen of het ontbreken van metingen voor sociale achtergrond de resultaten kunnen vertekenen. Dit geldt eveneens voor het kleine aantal hoger opgeleide niet-westerse immigranten in de EUFLS. Afgezien van een controle van deze zaken, zouden scherpere metingen van macrokarakteristieken de precisie van onze schattingen van de effecten kunnen verbeteren. Toekomstig onderzoek zou bijvoorbeeld het percentage allochtonen in een land verder kunnen onderverdelen in specifieke immigrantengroepen en de immigratiegeschiedenis verder kunnen uitsplitsen naar deze groepen en hun kenmerken (zoals het scholingsniveau waarmee zij uit hun land van herkomst vertrokken). Tevens kan verder onderzoek naar etnische ongelijkheden op de arbeidsmarkt zich richten op andere arbeidsmarktresultaten (zoals werkstatus of de duur van werkloosheid). Ten slotte kan het onderscheid tussen eerste generatie- en tweede generatieallochtonen nog meer inzichten geven omtrent etnische ongelijkheden op de arbeidsmarkt.

\section{Literatuur}

Abrassart, A. (2013). Cognitive skills matter: The employment disadvantage of low-educated workers in comparative perspective. European Sociological Review, 29 (4), 707-719.

Alba, R. \& Nee, V. (1997). Rethinking assimilation theory for a new era of immigration. International Migration Review, 37 (4), 826-874.

Altonji, J.G. \& Blank, R.M. (1999). Race and gender in the labor market. In O. Ashenfelter \& D. Card (red.), Handbook of Labor Economics (3143-3259). Amsterdam: Elsevier Science B.V.

Andriessen, I., Nievers, E., Dagevos, J. \& Faulk, L. (2012). Ethnic discrimination in the Dutch labor market: Its relationship with job characteristics and multiple memberships. Work and Occupations, 39 (3), 237-269.

Arrow, K. (1973). The theory of discrimination. In P. Ashenfelter, \& A. Rees (Eds.), Discrimination in labor markets. Princeton, NJ: Princeton University Press.

Becker, G.S. (1993). Human capital: A theoretical and empirical analysis with special reference to education. Chicago: University of Chicago Press.

Berthoud, R. (2000). Ethnic employment penalties in Britain. Journal of Ethnic and Migration Studies, 26 (3), 389-416.

Bertrand, M. \& Mullainathan, S. (2004). Are Emily and Greg more employable than Lakisha and Jamal? A field experiment on labor market discrimination. American Economic Review, 94 (4): 991-1013.

Black, D., Haviland, A., Sanders, S. \& Taylor, L. (2006). Why do minorities men earn less? A study of wage differentials among the highly educated. The Review of Economics and Statistics, 88 (2), 300-313.

Blommaert, L., Coenders, M. \& Van Tubergen, F. (2014). Discrimination of Arabic-named appli- 
cants in the Netherlands: An internet-based field experiment examining different phases in online recruitment procedures. Social Forces, 92 (3), 957-982.

Breen, R. (2005). Explaining cross-national variation in youth employment. European Sociological Review, 21 (2), 125-134.

Breen, R. \& Jonsson, J.O. (2005). Inequality of opportunity in comparative perspective: Recent research on educational attainment and social mobility. Annual Review of Sociology, 31, 223243 .

Brekke, I. (2007). Ethnic background and the transition from education to work among university graduates. Journal of Ethnic and Migration Studies, 33 (8), 1299-1321.

Brekke, I. \& Mastekaasa, A. (2008). Highly educated immigrants in the Norwegian labour market: Permanent disadvantage? Work, Employment \& Society, 22 (3), 507-526.

Carlsson, M. (2010). Experimental evidence of discrimination in hiring in the first and second generation immigrants. Labour: Review of Labour Economics and Industrial Relations, 24, 221357 .

Castles, S. \& Miller, M.J. (2003). The age of migration. New York: The Guildford Press.

Ceobanu, A.M. \& Escandell, X. (2010). Comparative analyses of public attitudes toward immigrants and immigration using multinational survey data: A review of theories and research. Annual Review of Sociology, 36, 309-328.

De Lange, M. Gesthuizen, M. \& Wolbers, M.H.J. (2014). Youth labour market integration across Europe: The impact of cyclical, structural and institutional characteristics. European Societies, 16 (2), 194-212.

DiPrete, T.A. \& Eirich, G.M. (2006). Cumulative advantage as a mechanism for inequality: A review of theoretical and empirical developments. Annual Review of Sociology, 32, 271-297.

Drange, I. (2013). Early-career income trajectories among physicians and dentists: The significance of ethnicity. European Sociological Review, 29 (2), 346-385

Gebel, M. \& Giesecke, J. (2011). Labor market flexibility and inequality: The changing skill-based temporary employment and unemployment risks in Europe. Social Forces, go (1), 17-39.

Gordon, M.M. (1964). Assimilation theory in American life. New York: Oxford University Press.

Gorodzeisky, A. \& Richards, A. (2013). Trade unions and migrant workers in Europe. European Journal of Industrial Relations, 19 (3), 239-254.

Hall, M. \& Farkas, G. (2012). Adolescent cognitive skills, attitudinal/behavioral traits and career wages. Social Forces, 89 (4), 1261-1285.

Heath, A.F., Rothon, C. \& Kilpi, E. (2008). The second generation in Western Europe: Education, unemployment, and occupational attainment. Annual Review of Sociology, 34, 211-235.

Helland, H. \& Støren, L.A. (2006). Vocational education and the allocation of apprenticeships: Equal chances for applicants regardless of immigrant background? European Sociological Review, 22 (3), 339-351.

Hermansen, A.S. (2013). Occupational attainment among children of immigrants in Norway: Bottlenecks into employment-equal access to advantaged positions? European Sociological Review, 29 (3), 517-534.

Kaas, L. \& Manger, C. (2012). Ethnic discrimination in Germany's labour market: A field experiment. German Economic Review, 13 (1), 1-20.

Kogan, I. (2006). Labor markets and economic incorporation among recent immigrants in Europe. Social Forces, 85 (2), 697-721.

Koopmans, R. (2010). Trade-offs between equality and difference: immigrant integration, multiculturalism and the welfare state in cross-national perspective. Journal of Ethnic and Migration Studies, 36 (1), 1-26.

Koopmans, R. (2013). Multiculturalism and immigration: A contested field in cross-national comparison. Annual Review of Sociology, 39, 147-169. 
Kornrich, S. (2009). Combining preferences and processes: An integrated approach to blackwhite labor market inequality. American Journal of Sociology, 115 (1), 1-38.

Levels, M., Dronkers, J. \& Kraaykamp, G. (2008). Immigrant children's educational achievement in western countries: origin, destination, and community effects of mathematical performance. American Sociological Review, 73, 835-853.

Lindbeck, A. \& Snower, D. (1988). The insider-outsider theory of employment and unemployment. Cambridge: MIT Press.

Lindbeck, A. \& Snower, D. (2002). The insider-outsider theory: a survey. IZA Discussion paper series, No. 534. Retrieved from: ftp://ftp.iza.org/RePEc/Discussionpaper/dp534.pdf

Livingston, G. (2006). Gender, job searching, and employment outcomes among Mexican immigrants. Population Research and Policy Review, 25, 43-66.

Luijkx, R. \& Wolbers, M.H.J. (2009). The effects of non-employment in early work-life on subsequent employment chances of individuals in the Netherlands. European Sociological Review, 25 (6), 647-66o.

Luthra, R.R. (2013). Explaining ethnic inequality in the German labor market: Labor market institutions, context of reception, and boundaries. European Sociological Review, 29 (5), 1095-1107.

Maas, I. \& Van Tubergen, F. (2006). Jeugdwerkloosheid onder immigranten en autochtonen in vijftien Europese landen, 1992-2001. In F. Van Tubergen \& I. Maas (red.), Allochtonen in Nederland in internationaal perspectief. Amsterdam: Amsterdam University Press.

Martinovic, B., van Tubergen, F. \& Maas, I. (2009). Changes in immigrants' social integration during the stay in the host country: The case of non-western immigrants in the Netherlands. Social Science Research, 38, 870-882.

Müller, W. \& Wolbers, M.H.J. (2003). Educational attainment in the European Union: Recent trends in qualification patterns. Oxford: Oxford University Press.

Noelke, C., Gebel, M. \& Kogan, I. (2012). Uniform inequalities: Institutional differentiation and the transition from higher education to work in post-socialist Central and Eastern Europe. European Sociological Review, 28 (6), 704-716.

OECD (2013), "Employment protection legislation: Strictness of employment protection legislation: individual and collective dismissals", OECD Employment and Labour Market Statistics (database). DOI: 10.1787/data-00658-en (accessed on 16 December 2014).

Pager, D. \& Karafin, D. (2009). Bayesian bigot? Statistical information, stereotypes, and employer decision making. Annals of the American Academy of Political and Social Science, 621 (1): 7093.

Pais, J.F. (2011a). Socioeconomic background and racial earning inequality: A propensity score analysis. Social Science Research, 40, 37-49.

Pais, J.F. (2011b). Multiethnic labor markets and socioeconomic mobility: A career trajectory perspective. Albany: State University of New York.

Parson, T. (1951). The social system. Glencoe: Free Press.

Petersen, T. \& Saporta, S. (2004). The opportunity structure for discrimination. American Journal of Sociology, 109 (4), 852-901.

Phelps, E. (1972). The statistical theory of racism and sexism. American Economic Review, 62, 659661.

Pichler, F. (2011). Success on European labour markets: A cross-national comparison of attainment between immigrant and majority populations. International Migration Review, 45 (4), 938-978.

Quillian, L. (2006). New approaches to understanding racial prejudice and discrimination. Annual Review of Sociology, 32, 299-328. 
Rafferty, A. (2012). Ethnic penalties in graduate level over-education, unemployment and wages: Evidence from Britain. Work, Employment and Society, 26 (6), 987-1006.

Reimer, D., Noelke, C. \& Kucel, A. (2008). Labor market effects of field of study in comparative perspective: An analysis of 22 European countries. International Journal of Comparative Sociology, 49 (5-6), 233-256.

Reitz, J.G. (2002). Host societies and the reception of immigrants: Research themes, emerging theories and methodological issues. International Migration Review, 36 (4), 1005-1019.

Reskin, B. 1991. "Labor markets as queues: A structural approach to changing occupational sex composition." Pp. 170-92 in Macro-micro interrelationships in sociology, edited by Joan Huber. Thousand Oaks, Calif.: Sage Publications.

Reyneri, E. \& Fullin, G. (2011). Labor market penalties of new immigrants in new and old receiving West European countries. International Migration, 49 (1), 31-57.

Rijken, S. (1999). Educational expansion and status attainment: A cross-national and overtime comparison. Radboud Universiteit Nijmegen.

Scheepers, P. Gijsberts, M. \& Coenders, M. (2002). Ethnic exclusionism in European countries: Public opposition to civil rights for legal migrants as a response to perceived ethnic threat. European Sociological Review, 18 (1), 17-34.

Shavit, Y., Arum, R. and Gamoran, A. (2007). Stratification in higher education: A comparative study. Stanford: Stanford University Press.

Shavit, Y. \& Müller, W. (1998). From school to work: A comparative study of educational qualifications and occupational destinations. Oxford: Clarendon Press.

Tomaskovic-Devey, D., Thomas, M. \& Johnson, K. (2005). Race and the accumulation of human capital across the career: A theoretical model and fixed-effects application. American Journal of Sociology, 11 (1), 58-89.

Urban, S. (2012). University education as a compensation strategy among second-generation immigrants. International Migration Review. 46 (4), 919-940.

Van Tubergen, F. (2006). Immigrant integration: A cross-national study. New York: LFB Scholarly Publishing.

Van Tubergen, F., Maas, I. \& Flap, H. (2004). The economic incorporation of immigrants in 18 Western societies: Origin, destination, and community effects. American Sociological Review, 69 (5), 704-727.

Willemse, N. \& De Beer, P. (2012). Three worlds of educational welfare states? A comparative study of higher education systems across welfare states. Journal of European Policy Making, $22(2)$, 105-117.

Wolbers, M.H.J. (2007). Patterns of labour market entry: A comparative perspective on school-towork transitions in 11 European countries. Acta Sociologica, 50 (3), 189-210.

\title{
Over de auteurs
}

Niels Raaijmakers is student aan de Research Master Social and Cultural Sciences van de Radboud Universiteit Nijmegen.

\author{
Lex Thijssen is student aan de Research Master Social and Cultural Scien- \\ ces van de Radboud Universiteit Nijmegen.
}


Dr. Maurice Gesthuizen is Universitair Docent Sociologie aan de Radboud Universiteit Nijmegen.

Prof. dr. Maarten H.J. Wolbers is hoofd sector Onderwijs van het Radboud ITS en bijzonder hoogleraar Onderzoek van onderwijs, Radboud Universiteit Nijmegen. 